cisions, particularly vital in gross hand injuries. By constantly regarding the hand as a composite functioning unit, the optimum ultimate result may be achieved for in the author's words: 'Hand surgery must not be fragmented into separate systems.'

Only too often extensor tendon injuries are considered to present no difficulty in repair with the aim of a good or even excellent result easily achieved and this in spite of the indifferent results frequently following the commonest extensor lesion, the mallet finger. In drawing attention to the peculiar and largely anatomical problems attending these injuries Bank and Wakefield aim at a degree of perfection which exemplifies the high standard they set in the treatment of all hand injuries.

Sections of particular interest in a well-planned work are those on the surgical anatomy of the hand and the special aspects of burns and injuries in children. The book is profusely illustrated by photographs and line drawings and well-produced. by the publishers.

\section{TEXTBOOK OF GENETICS}

By William Hovanitz, Ph.D. Pp. $x+419$, with 267 illustrations. London: Elsevier Publishing Co., Ltd. Distributors Cleaver-Hume Press. 1953. 42s. 6d.

The scope of Professor Hovanitz's book is considerable and it is probable that some of its less satisfactory features are due to the endeavour to compress too much information into too few pages. A short preface reminds the reader of what he should know and may have forgotten and also gives a summary of the author's philosophical approach to genetics. In common with the rest of the book, and with a greater frequency, the preface is marred by what appear to be printer's errors and also by examples of almost meaningless phraseology. For the most part, however, the book is clearly written. Excellent introductory chapters deal with Mendelism and explain the mathematics of probability, but the manner of presentation of some later chapters is less happy. For instance the statement is made that achondroplasia is a simple inherited condition which usually appears as a dominant; this statement is accompanied by a pedigree in which the symbols are unexplained, but whatever interpretation one gives to them the pedigree does not appear to illustrate the behaviour of a dominant. Similarly the references to the inheritance of comb-structure of the fowl, although undoubtedly quite clear to a practiced geneticist would be difficult for a student or non-specialist to understand because they contain words used in an inexact manner. The sections dealing with plant genetics are accompanied by an excellent account of gametogenesis and embryogenesis of plants - an account that many writers of botanical textbooks might well study. The chromosome is described very clearly both from the cytological and cytochemical aspects. Most of the remainder of the book deals with complicated genetical phenomena, some of which, notably the shell-coiling of snails, are dismissed so concisely as to be incomprehensible. In this example matters are not improved by a textual error that has introduced a new and unexplained gene. Modern studies of the genetics of bacteria are scarcely touched on; viruses are not mentioned.

At intervals the book contains unanswered questions designed to arouse curiosity and the desire to investigate. Surely no one but a serious student would be reading this work and he would be better helped by questions to which he could check his answer. The omission of adequate references to work cited is a grave fault and should be rectified in any subsequent edition. In general, however, the book is stimulating and informative and provides a useful addition to the literature of the subject. A.F.

\section{M.R.C. Special Report Series, No. 280 VITAMIN C REQUIREMENT OF HUMAN ADULTS}

A Report by the Vitamin C Sub-Committee of the Accessory Food Factors Committee

Compiled-by W. Bartley, H. A. Krebs and J. R. P. O'Brien. Pp. viii + I79, with 24 illustrations, 6 in colour. London: H.M.S.O. 1953. 17s. 6d.

This publication contains the detailed aspects of the vitamin $\mathrm{C}$ deprivation experiment carried out on human volunteers towards the end of the war. A brief report of the main findings appeared in The Lancet in 1948. A detailed index is lacking but the subdivision into three main sections allows easy reference to the many clinical, biochemical and metabolic aspects of vitamin $\mathrm{C}$ deficiency that have been covered. Many of the earlier problems of the diagnosis of scurvy have been overcome by diligent observation which forms a striking characteristic in this brilliant experiment. The relative inadequacy of biochemical methods as compared with clinical observation in the diagnosis of early scurvy is well illustrated and previous reports that wound healing becomes delayed only after the appearance of clinical scurvy are confirmed. In the achievement of its primary object, however, the report is outstanding in that it presents convincing evidence that the minimum daily requirement of vitamin $C$ for the prevention of scurvy in healthy adults not undertaking strenuous physical work is in the region of only ro mg.

To those with special interests in vitamin C metabolism criticism could only be levelled in that the publication was not more detailed in certain aspects. The comparatively large section devoted to follicular hyperkeratosis stresses the importance of this physical sign as a simple diagnostic tool but little mention is made of its characteristic distribution and the possible influence, as seen in this survey, that clothing or other external agents may have in this regard. Those with experience of clinical scurvy will note that the stage of extensive ecchymoses and intramuscular haematomata was not reached in this study and may feel that this 
should have been stressed when conclusions were drawn regarding haematological aspects and other features commonly seen in severe adult scurvy. These criticisms, however, should in no way detract from the value of this publication to surgeons, dentists, dermatologists and research workers, both for the results that are contained therein and for the manner in which this trial was planned and conducted.

\section{AN INTRODUCTION TO GENERAL PRACTICE}

By D. Craddock, M.B., Ch.B., D.Obst.R.C.O.G.

Pp. xvi + 552. London: H. K. Lewis \& Co.

Ltd. 1953. $42 \mathrm{~s}$.

This book has been written with the idea of helping those new to general practice. It deals largely with the complaints and problems found in general practice, and it amplifies on many points left untouched by the usual text books. Some idea of its approach can be got from chapter headings, e.g. 'The patient who asks for a tonic,' 'Trivial complaints,' ' The child who won't eat,' ' Chronic disorders and their management,' etc. There are sections on entry into general practice, paper work, and the doctor's bag, to mention only a few of the parts not directly dealing with illness itself. In fact all aspects of a general practitioner's daily life are dealt with.

It is a book impressive in its common sense approach to medicine, and encouraging in the picture it paints of practice as it can be. Any doctor who is either contemplating general practice or about to enter it will find this book enormously valuable, and a thoroughly sound basis for his preparation for practice.

\section{SHOULDER LESIONS}

By H. F. Moseley, D.M., F.R.C.S., F.A.C.S. 2nd Edition. Pp. 329, with 216 illustrations and 4I coloured plates. London: Cassell \& Co. Ltd. 1953. 90s.

The shoulder has long been a fascinating joint for special study, for it presents important problems of pathology and diagnosis, as well as of treatment. In the field of pathology, for instance, we still have much to learn about the causes and mechanism of the degenerative changes that are seen so commonly in the short ' cuff' muscles, and about the formation of calcified deposits within the supraspinatus tendon. More baffling still is the problem of that striking clinical condition, ' frozen shoulder.' What are its nature and cause ? And what is its relationship, if any, to the shoulderhand syndrome? In the field of diagnosis much attention has been given recently to the early differentiation between major tears of the supraspinatus tendon and the contusions, strains and other injuries with which such tears may be confused. Early diagnosis is important, because seemingly it is only by early operation that a reasonable chance of successful repair can be assured: and even then the results are far from brilliant.

All these and many other aspects of shouldeס surgery are ably discussed by Mr. H. F. Moseleyin the second edition of his already well known - book. The author has been able to draw upon 2 vast personal experience, and it is evident that his material has been most carefully documented and studied against a background of the previous literature on the subject. The discussion is full and interesting, even though nothing startlingl\% new emerges. In most respects the author's ideass correspond closely with those of surgeons fromb Great Britain who have a special interest in the shoulder. This is true even in the matter oft fractures, the treatment of which on the other side of the Atlantic has sometimes been regarded witk a certain suspicion by surgeons from this country 3 . They believe that in some centres there has beeniw too much emphasis on the physical restoration of the bony anatomy by fastening the fragmentss together with screws, plates, nails or other ' hard $\frac{N}{N}$ ware,' whereas the importance of restoring function has been by contrast neglected. The following quotation will therefore be refreshing to those who are of that mind. Referring to the treatment of fractures of the neck of the humerus, the autho $\vec{b}$ writes: 'Thete is one method .. which merit more consideration than it has yet received. It is the treatment of these cases by immediate moge $\overrightarrow{0}$ ment, massage and thermal therapy. By immediater movement, the author means the earliest possifle function in the relaxed muscle position, activated 95 the patient's own volition and under expert super vision.' 'Throughout the book there is an emphasio on the importance of preserving and restoring function by active use and active exercise. This reflects an enlightened outlook; for if there is any one factor that has been responsible more tharp another for improved results in the treatment of orthopaedic disorders it is surely the recognition that the patient must be made to restore his own? function by his own activities. He can be super vised and guided along the right paths, but function. cannot be restored for him while he remains passive-

The book is handsomely produced, but the critical reader will be disappointed to find that the arrangement and the lay-out could be improved 3 And excellent though the numerous coloureof illustrations are, their value is impaired by inades quate captions: If these points are given attention in a future edition, a first-class work will have beene. achieved.

$$
\text { J.C.A. 요 }
$$

\section{THE MEGALOBLASTIC ANAEMIAS}

By L. J. Davis, M.D., F.R.C.P., F.R.C.P.E F.R.F.P.S.G., F.R.E., and A. BROwN, M.D. F.R.C.P.E., F.R.F.P.S.G. Pp. xi + i 13, wiț I2 illustrations. Oxford: Blackwell Scientific Publications. 1953. 21s.

This book is a model of all that a medical mono 